\title{
Examining the Factors Affecting Sovereign Credit Rating of Gulf Cooperation Council Countries
}

\author{
Yaser A. AlKulaib ${ }^{1} \&$ Musaed S. AlAli ${ }^{2}$ \\ ${ }^{1}$ Department of Finance and Financial Institutions, College of Business Administration, Kuwait University, Kuwait \\ ${ }^{2}$ Department of Insurance and Banking, College of Business Studies, The Public Authority for Applied Education \\ and Training (PAAET), Kuwait \\ Correspondence: Musaed S. AlAli, Department of Insurance and Banking, College of Business Studies, The Public \\ Authority for Applied Education and Training (PAAET), Kuwait.
}

Received: August 18, 2020

Accepted: October 13, 2020

Online Published: December 24, 2020

doi:10.5430/ijfr.v12n1p12

URL: https://doi.org/10.5430/ijfr.v12n1p12

\begin{abstract}
Despite the controversy surrounding the credibility of credit rating agencies' rating systems, these agencies' ratings still play a crucial role in determining the premium paid by governments on their bonds. As a result, obtaining a high sovereign credit rating would lower borrowing costs and more demand for their bonds. In order to do so, policymakers should be aware of the factors that mostly affect the sovereign credit rating of their countries. While there are many factors credit rating agencies consider when assigning a sovereign credit rating for any country, this study aims to identify the factors that mostly affect Gulf Cooperation Council (GCC) countries' sovereign credit ratings assigned by the biggest three credit rating agencies, Standard and Poor's (S\&P), Moody's, and Fitch. This study is based on the Gulf Cooperation Council (GCC) data 2012-2018. Results obtained from this research show that interest rate, government debt to GDP ratio, GDP per capita, and the labeling of the country as developed or developing country was the variables that mostly affect the S\&P rating. GDP per capita and government debt to GDP were the factors that most influenced Moody's scores. In contrast, GDP, interest rate, transparency score, government debt to GDP, and GDP per capita were the factors that most affect Fitch's credit rating scores. The results also revealed that in 2018, Kuwait was the most overrated country, while Oman was the most underrated country.
\end{abstract}

Keywords: sovereign credit rating, Gulf Cooperation Council (GCC), Credit Rating Agencies (CRAs), default, corruption index, Human Development Index (HDI)

\section{Introduction}

The Gulf Cooperation Council (GCC) is a council formed in 1981 by six countries: Kuwait, Saudi Arabia, United Arab Emirates, Qatar, Bahrain, and Oman to face any challenges in the Arabian Gulf area. The council countries are significant players in the world energy market. According to OPEC's 2018 annual report, GCC countries account for $21 \%$ of the world oil production market and $10.8 \%$ of natural gas production. They also have proven oil reserves that account for $30.56 \%$ of total world reserves and $20.95 \%$ gas. The GCC countries depend on their energy exports as their primary source of income. According to an IMF report (2016), oil and gas sales account for about $80.48 \%$ of their income, which makes them vulnerable to any price shocks in the oil and gas markets. In the past few years, these countries started adapting new visions to diversify their income sources rather than relying only on their energy exports. In achieving such a goal, they are required to finance large projects through international markets, and for that, they are required to maintain high sovereign credit ratings to reduce their cost of borrowing. According to Afonso et al. (2007), sovereign credit rating has many impacts, such as the country's borrowing costs. It sets an upper cap to the credit rating of any institution inside that country. Finally, some institutional investors have a bottom limit to what investments they can add to their bonds portfolio, which means that the higher a country credit rating is, the more investors invest in its bonds.

According to Fahmi et al. (2008), credit risk is defined as the potential losses due to the borrower's failure to meet the contractual obligation to pay his debt. A country's sovereign risk is the bond issuing country's inability to repay the debt principal and interest. What differentiates sovereign debt from corporate debt is the absence of bankruptcy code 4. Unlike corporate bonds, where the bondholder would have the right to access the obligor's assets when the 
bond issuer defaults, sovereign bond holders do not have that option. The default on the Russian GKO bonds in August 1998 illustrates such a problem. For that, a sovereign borrower's creditworthiness depends not only on its ability but also on its willingness to pay its debt (Clark, 1997; Clark \& Zenaidi, 1999). Bheenick (2005) stated that, according to the founder of Moody's, John Moody, a credit rating indicated the creditworthiness of a government by assessing two main aspects: "capability to pay and willingness to pay."

A country's sovereign credit rating is issued by credit rating agencies, which are private companies whose purpose is to assess borrowers' ability, either governments or private enterprises, to repay their debt. To do so, these agencies issue credit ratings based on the borrower's solvency. While there are several credit rating agencies, the three largest global rating agencies, Standard and Poor's (S\&P), Fitch Rating Ltd, and Moody's, control 95\% of the global credit rating market (Pirdal, 2017). These credit-rating agencies (CRAs) have a significant effect on investors' decisions and their portfolios' structure. Many investors give credit rating a lot of consideration in their investment decisions. This trust has enabled CRAs to play a central role in financial markets. Many researchers warn investors not to rely only on credit ratings provided by these CRAs and to conduct their due diligence. Zheng (2012) believes that CRAs' reliability became questionable after giving a false rating to some countries, such as Thailand and Korea in 1997/1998. Duran and Doruk (2016) criticized CRAs for their inability to foresee the 2008 financial crisis and failure to capture the deterioration in many countries' credit risk before the crisis. Duran and Kucuksarac (2017) concluded from their study that, on an average, emerging countries had 1.4 notches lower credit ratings than developed countries, with similar macroeconomic indicators, indicating biases toward developed countries' scores.

CRAs use a number of variables that differ from one agency to another in assessing sovereign credit rating. These variables include economic variables that are quantitative variables and social and political variables that are qualitative. Haque et al. (1998) indicated that the economic variables could explain a large portion of its creditworthiness ratings. Lee (1993) concluded that economic variables have more influence than political variables in determining sovereign ratings. Cantor and Packer (1996) conducted a study on the factors affecting the sovereign credit rating of 49 countries, as of September 1995, using the assigned credit ratings from S\&P and Moody's. They concluded that six out of the eight variables they used had a statistically significant effect on these countries' credit ratings. They found that per capita income, GDP growth, inflation, external debt, an indicator of economic development set by the International Monetary Fund in classifying the country as industrialized or not, and default history had the most effect on the sovereign credit rating for the countries under study. They also concluded that macroeconomic variables could explain about $80 \%$, which is more than enough to say that economic factors are the main factor for the sovereign rating. Hamdi et al. (2014) studied the sovereign credit rating created by Moody's and Fitch for 23 emerging countries and found that GDP per capita, government debt per capita, inflation, CPI, and central bank reserves had a significant effect on sovereign rating. Afonso (2003) conducted a study for 81 developed and developing countries using several quantitative and qualitative variables as of June 2001 and compared his results to the ratings assigned by Standard \& Poor's and Moody's. He concluded that GDP per capita, external debt, economic development level, default history, real growth rate, and inflation rate were relevant for a country's credit rating. Duran and Kucuksarac (2017) conducted a study on 13 emerging and 16 developed countries from 2008 to 2014 using Fitch's sovereign rating. Their results showed that GDP growth, government debt, GDP volatility, and inflation volatility were the factors that most affected the credit rating of developed countries. While in terms of emerging countries, inflation, government debt, financial depth, and GDP per capita were the factors that had a statistically significant effect on their ratings.

This study aims to examine ten variables and their effect on GCC sovereign credit rating. These variables and their rational expectations, between brackets, include:

\subsection{Gross Domestic Product (GDP) (+)}

Gross domestic product (GDP) indicates the economic strength of the country. A relatively high GDP suggests that a country's existing debt burden will become easier to service over time. The energy market that all GCC countries depend on is a volatile market, which would result in fluctuations in their GDP, affecting their sovereign rating. The rationale behind GDP is that countries with high incomes would be more capable of honoring their financial obligations.

\subsection{GDP Growth (+)}

Positive GDP growth would indicate that the country is making the most out of their debt and, therefore, more capable of repaying them. Positive GDP growth would also suggest that the country is getting more income and will be better positioned to repay its debts. Previous studies by Cantor and Packer (1996) and many others demonstrate a strong relationship between GDP growth and the country's sovereign credit rating. 


\subsection{Inflation (-)}

Imported inflation is a significant concern for GCC countries due to the fixed foreign exchange system to the U.S. Dollar they use. With the U.S. devaluing its currency to promote its exports, such a move would result in a higher cost of imports for GCC countries and higher inflation. AlAli (2016) studied the effect of adopting a pegged exchange rate on the profitability of carrying trade for United Arab Emirates Dirham (AED) and found that adopting such an exchange rate system caused imported inflation to the Emirates' economy, causing high inflation rates. While on the other hand, Kuwait abandoned the pegged exchange rate system and moved to a basket of currencies without revealing the basket's components to reduce imported inflation (Moosa \& Al-Loughani, 2000; AlAli et al., 2017). Samuelson and Nordhaus (1985) stated that high inflation could distort the economy, causing political instability. Zheng (2012) found that high inflation displays the government's inability or unwillingness to fund the budget expenses through a tax increase, reducing its ability to repay its debt.

\subsection{Interest Rate (-)}

Five out of the six GCC countries, except Kuwait, follow a pegged exchange rate system to peg their currencies to the U.S. dollar. As a result of adopting such a scenario, these countries lost their control over their monetary instruments and were required to follow the US interest rate. Any divergence from the US interest rate would result in an arbitrage opportunity for carrying traders. Resulting foreign exchange attacks would disrupt their central bank foreign currency reserves and would eventually affect their ability to repay their debt in foreign currencies (AlAli, 2015). As a result of the adaptation of fixed exchange rates, finding a high correlation between inflation and interest rate is highly unlikely.

\subsection{Corruption (-)}

Hamdi et al. (2014) define corruption as "a misappropriation of trust or authority for the personal interest, may have a negative effect on every person in that authority." Mellios and Blanc (2004) and Minescu (2010) argued that corruption is an essential factor that affects any country's credit rating since a high corruption level would indicate the government system's failure and eventually lead to a higher chance of default. Mauro (1995) found an inverse relationship between corruption and economic growth, which affects the country's ability to honor its financial obligations. Frisch (1995) added that corruption would increase the cost of goods and services and ignite political instability.

In determining corruption, the Corruption Perceptions Index (CPI) is used. CPI is an index published annually by Transparency International, since 1995, which ranks countries "by their perceived levels of public sector corruption." The CPI generally defines corruption as "the misuse of public power for private benefit." CPI has a scoring system ranging from 0 (extremely corrupt) to 100 (very clean).

\subsection{GDP Per Capita (+)}

A higher GDP per capita would imply a higher income per capita. With the new sales tax GCC countries imposed recently and the proposed income tax, this would indicate more income for these countries and a higher capability to repay their debts. Studies by many, such as Afonso (2003), Hamdi et al. (2014), Duran and Kucuksarac (2017), and others showed a strong positive relationship between GDP per capita and sovereign credit rating.

\subsection{Government Debt to GDP (-)}

Mankiw (2007) defines government debt as a debt accumulation that happens when the government has more expenses than income, forcing the government to borrow from international markets to cover the deficit. The government debt to GDP ratio measures government leverage. A lower ratio would imply a healthier financial position for the country towards its financial obligations, reducing the default probability. Hamdi et al. (2014) concluded in their research that government debt to GDP has a significant negative effect on the country's credit rating.

\subsection{Human Development Index (+)}

A healthy and well-educated population would result in higher productivity and higher economic growth in any country. Achieving such high growth would result in a stronger economy and would mean more ability to fulfill its sovereign bonds' financial obligations. This variable is measured by the human development index (HDI), an index found in 2010 by the United Nations development program. It is a statistic composite index of life expectancy, education, and per capita income indicators used to rank countries into four tiers of human development. Countries with scores ranging from 1.00 to 0.80 are labeled as very high, 0.799 to 0.70 as high, 0.699 to 0.555 as medium, and 
0.554 to 0.350 as low countries. Hill and Faff (2010), using the data of 101 countries over the period 1990-2006, found that HDI had a statistically significant effect on these countries' sovereign credit rating.

\subsection{Classification of Developed or Developing (+)}

While the World Bank sets a threshold of $\$ 12,376$ for high-income countries in 2018, Cantor and Packer (1996) stated that countries with high sovereign ratings had a median income per capita of $\$ 25,000$. In this study, countries that achieve both a GDP per capita of more than $\$ 25,000$ and human development index (HDI) that exceeds 0.8 are classified as developed countries, while countries that do not meet these conditions are classified as developing countries.

\subsection{Country Reserves (+)}

Having large central bank reserves works as a shock absorber against any downside move in the country's income and will make that country more capable of facing any financial obligations toward its sovereign bonds. Minesuc (2010) stated that having a high reserve would significantly increase the country's ability to repay its debt.

\section{Methodology}

CRAs use alphabetical symbols to assign credit ratings. To quantify such a scale, an equivalent numerical rating system is set as in Table 1 .

Table 1. Credit rating agencies comparison and numerical rating

\begin{tabular}{|c|c|c|c|c|c|}
\hline Grade & $\begin{array}{l}\text { Numerical } \\
\text { Rating }\end{array}$ & Moody’s & $\mathrm{S} \& \mathrm{P}$ & Fitch & Meaning \\
\hline \multirow{10}{*}{$\begin{array}{l}\text { Investment } \\
\text { Grade }\end{array}$} & 23 & Aaа & AAA & AAA & Prime \\
\hline & 22 & Aa1 & $\mathrm{AA}+$ & $\mathrm{AA}+$ & \multirow{3}{*}{ High Grade } \\
\hline & 21 & $\mathrm{Aa} 2$ & AA & $\mathrm{AA}$ & \\
\hline & 20 & Aa3 & AA- & AA- & \\
\hline & 19 & A1 & $\mathrm{A}+$ & $\mathrm{A}+$ & \multirow[t]{3}{*}{ Upper Medium Grade } \\
\hline & 18 & $\mathrm{~A} 2$ & A & A & \\
\hline & 17 & A3 & A- & A- & \\
\hline & 16 & Baa1 & $\mathrm{BBB}+$ & $\mathrm{BBB}+$ & \multirow[t]{3}{*}{ Lower Medium Grade } \\
\hline & 15 & Baa2 & BBB & BBB & \\
\hline & 14 & Baa3 & BBB- & BBB- & \\
\hline \multirow{13}{*}{$\begin{array}{l}\text { Speculative } \\
\text { Grade }\end{array}$} & 13 & Ba1 & $\mathrm{BB}+$ & $\mathrm{BB}+$ & \multirow{3}{*}{$\begin{array}{l}\text { Non-Investment } \\
\text { Speculative }\end{array}$} \\
\hline & 12 & $\mathrm{Ba} 2$ & $\mathrm{BB}$ & $\mathrm{BB}$ & \\
\hline & 11 & $\mathrm{Ba} 3$ & BB- & BB- & \\
\hline & 10 & B1 & $\mathrm{B}+$ & $\mathrm{B}+$ & \multirow[t]{3}{*}{ Highly Speculative } \\
\hline & 9 & B2 & B & B & \\
\hline & 8 & B3 & B- & B- & \\
\hline & 7 & Caa1 & $\mathrm{CCC}+$ & $\mathrm{CCC}+$ & Substantial Risks \\
\hline & 6 & Caa2 & $\mathrm{CCC}$ & $\mathrm{CCC}$ & Extremely Speculative \\
\hline & 5 & Caa3 & CCC- & CCC- & \multirow{2}{*}{$\begin{array}{l}\text { In Default with Little } \\
\text { Prospect for Recovery }\end{array}$} \\
\hline & 4 & $\mathrm{Ca}$ & $\mathrm{CC}$ & $\mathrm{CC}+$ & \\
\hline & 3 & & $\mathrm{C}$ & $\mathrm{CC}$ & \multirow{3}{*}{ In Default } \\
\hline & 2 & & & $\mathrm{CC}-$ & \\
\hline & 1 & D & D & DDD & \\
\hline
\end{tabular}

Source: Destraz and Lahaye (2012). The numerical rating is set by the author for calculation purposes. In any calculation onward, the number produced is rounded. 
This study uses the ordinary least squared regression method (OLS) to examine the relationship between sovereign credit rating score as the dependent variable and ten independent variables. The equation of panel regression used in this research is as follow:

$$
\ln R_{t}=c+\operatorname{lnGDP_{t}}+\Delta G D P_{t}+\operatorname{lnGdpcap_{t}}+\operatorname{Govgdp}_{t}+C P I_{t}+I r_{t}+\operatorname{Infl}_{t}+\operatorname{Dev}_{t}+H D I_{t}+\operatorname{lnCR_{t}}+\varepsilon_{t}(1)
$$

$\ln R_{t}$ is the natural logarithm of the numerical score of the rating. $\ln G D P_{t}$ is the natural logarithm of gross domestic product (GDP). $\triangle G D P_{t}$ is the GDP growth. $\operatorname{lnGdpcap}_{t}$ is the natural logarithm of GDP per capita. Govgdp $p_{t}$ is the government debt to GDP. $C P I_{t}$ is the corruption perception index score. $I r_{t}$ is the interest rate. Infl $l_{t}$ is the inflation rate. $D e v_{t}$ is whether or not the country is considered as a developed country or not. $H D I_{t}$ is the human development index score. $\ln C R_{t}$ is the natural logarithm of country reserves. $\varepsilon_{t}$ is the error term.

\section{Data and Empirical Results}

This study aims to determine the factors that mostly affect the sovereign credit rating of GCC countries assigned by S\&P, Moody's, and Fitch credit rating agencies. A panel data was used for the period 2012-2018. The data for this research were obtained from the IMF, World Bank websites, and the United Nations development program.

Descriptive analysis is presented in Table 2, where it can be seen that the average S\&P rating for the six GCC countries was 18.168, which is equivalent to an A rating. During the study period, the GCC countries' average GDP growth was $2.6 \%$, and the inflation rate was $2.1 \%$. On average, the six countries had a government debt to GDP ratio of $29 \%$ and a GDP per capita of $\$ 34,150$. To assess the data's normality, examining skewness (symmetry of the distribution) and kurtosis (sharpness of the peak of a frequency-distribution curve) are required. According to Klein (1998), for data to be normally distributed, skewness value should be between \pm 3 and \pm 10 for kurtosis. By looking at the descriptive analysis in Table 2, it can be seen that the data is normally distributed.

Table 2. Descriptive analysis

\begin{tabular}{|c|c|c|c|c|c|c|c|c|c|c|c|}
\hline & $\begin{array}{l}\text { Credit } \\
\text { Rating }\end{array}$ & $G D P$ & Chng & Infl & $I r$ & $C P I$ & Govgdp & Gbpcap & $H D I$ & Dev & $C R$ \\
\hline Mean & 18.167 & 255.287 & 0.026 & 0.021 & 0.015 & 52.881 & 0.290 & 34150.72 & 0.832 & 0.524 & 127.278 \\
\hline Median & 20 & 166.125 & 0.040 & 0.021 & 0.011 & 49.000 & 0.207 & 28345.00 & 0.834 & 1.000 & 32.669 \\
\hline $\begin{array}{l}\text { Standard } \\
\text { Deviation }\end{array}$ & 3.371 & 237.999 & 0.099 & 0.011 & 0.007 & 11.238 & 0.243 & 17430.05 & 0.023 & 0.505 & 213.519 \\
\hline Kurtosis & -0.047 & -0.042 & 1.796 & -0.414 & -0.313 & -1.250 & 1.467 & -0.04 & -0.695 & -2.092 & 2.202 \\
\hline Skewness & -1.086 & 1.116 & -1.236 & -0.390 & 0.753 & 0.486 & 1.283 & 1.07 & -0.461 & -0.099 & 1.927 \\
\hline Minimum & 10 & 30.750 & -0.296 & -0.008 & 0.008 & 36.000 & 0.016 & 16144.40 & 0.781 & 0.000 & 2.442 \\
\hline Maximum & 21 & 782.483 & 0.174 & 0.041 & 0.035 & 71.000 & 1.020 & 70780.00 & 0.863 & 1.000 & 726.849 \\
\hline Count & 42 & 42 & 42 & 42 & 42 & 42 & 42 & 42 & 42 & 42 & 42 \\
\hline
\end{tabular}

Correlation analysis measures the strength and the nature of the relationship between variables where it takes a value between -1 and 1 . The correlation analysis can also be used to identify any multicollinearity in the data. Multicollinearity can cause unrealistically high standard error estimates of regression coefficients and, in the end, can cause false conclusions about the significance of independent variables in the model evaluated. Ejigu (2016) identified 0.80 as the threshold for multicollinearity, and, on the other hand, Kramaric et al. (2017) used 0.70. In this research, a threshold of 0.70 is used to identify multicollinearity. Using the Pearson correlation matrix in Table 3 , it can be seen that such a problem exists between GDP and the country reserve, 0.92. For that country, reserve is eliminated from equation 1. 
Table 3. Pearson correlation matrix

\begin{tabular}{|c|c|c|c|c|c|c|c|c|c|c|}
\hline & GDP & Chng & Infl & $\mathrm{Ir}$ & CPI & Govgdp & Gbpcap & HDI & Dev & $\mathrm{CR}$ \\
\hline GDP & 1.00 & & & & & & & & & \\
\hline Chng & 0.04 & 1.00 & & & & & & & & \\
\hline Infl & 0.00 & -0.19 & 1.00 & & & & & & & \\
\hline $\mathrm{Ir}$ & -0.27 & 0.24 & -0.24 & 1.00 & & & & & & \\
\hline CPI & 0.18 & -0.07 & 0.02 & -0.48 & 1.00 & & & & & \\
\hline Govgdp & -0.50 & 0.20 & -0.12 & -0.06 & -0.11 & 1.00 & & & & \\
\hline Gbpcap & -0.09 & -0.02 & 0.09 & -0.38 & 0.69 & 0.14 & 1.00 & & & \\
\hline HDI & 0.45 & -0.03 & -0.04 & -0.48 & 0.53 & 0.31 & 0.44 & 1.00 & & \\
\hline Dev & -0.13 & -0.05 & 0.16 & -0.11 & 0.51 & 0.01 & 0.77 & 0.21 & 1.00 & \\
\hline CR & 0.92 & 0.00 & 0.02 & -0.23 & -0.11 & -0.42 & -0.28 & 0.30 & -0.39 & 1.00 \\
\hline
\end{tabular}

The data processing results for the variable that might affect the sovereign credit rating of the big three CRAs are presented in Table 4. As shown in the table, the model achieved a significant $F$ that was lower than 0.01, which means that it is safe to label it as a good fit. The table also shows that it had the highest explanatory power when used to estimate $\mathrm{S} \& \mathrm{P}$ rating scores with an adjusted $R$ square of 0.915 , while the model showed the least explanatory power when used to estimate Fitch's credit rating scores.

Table 4. Regression output

\begin{tabular}{|c|c|c|c|c|c|c|c|c|c|}
\hline \multicolumn{4}{|l|}{$\mathrm{S} \& \mathrm{P}$} & \multicolumn{3}{|l|}{ Moody's } & \multicolumn{3}{|l|}{ Fitch } \\
\hline R Square & 0.934 & & & 0.926 & & & 0.915 & & \\
\hline Adj R Square & 0.915 & & & 0.905 & & & 0.891 & & \\
\hline Observations & 42 & & & 42 & & & 42 & & \\
\hline Significance F & 0.000 & & & 0.000 & & & 0.000 & & \\
\hline & Coefficients & $t$ Stat & $P$-value & Coefficients & $t$ Stat & $P$-value & Coefficients & $t$ Stat & $P$-value \\
\hline Intercept & 2.180 & 2.848 & $0.008 * * *$ & 0.526 & 0.683 & 0.500 & 1.105 & 1.347 & 0.188 \\
\hline $\operatorname{lnGDP}$ & 0.034 & 1.258 & 0.217 & 0.014 & 0.511 & 0.613 & 0.083 & 2.916 & $0.006 * * * *$ \\
\hline Chng GDP & 0.016 & 0.134 & 0.894 & -0.061 & -0.505 & 0.617 & -0.056 & -0.434 & 0.667 \\
\hline Infl & -0.910 & -0.936 & 0.356 & -1.496 & -1.529 & 0.136 & -0.010 & -0.010 & 0.992 \\
\hline Ir & -4.004 & -2.024 & $0.051 *$ & 0.360 & 0.181 & 0.858 & -4.841 & -2.281 & $0.029 * *$ \\
\hline $\operatorname{lnCPI}$ & -0.050 & -0.623 & 0.538 & 0.025 & 0.313 & 0.756 & -0.217 & -2.509 & $0.017 * *$ \\
\hline Govgdp & -0.550 & -4.812 & $0.000 * * *$ & -0.647 & -5.636 & $0.000 * * *$ & -0.300 & -2.452 & $0.020 * *$ \\
\hline lngdpcap & 0.202 & 3.430 & $0.002 * * *$ & 0.307 & 5.199 & $0.000 * * *$ & 0.230 & 3.657 & $0.001 * * * *$ \\
\hline HDI & -1.403 & -1.275 & 0.212 & -0.847 & -0.765 & 0.450 & -0.037 & -0.031 & 0.976 \\
\hline Dev & 0.099 & 2.103 & $0.043 * *$ & -0.062 & -1.310 & 0.199 & 0.064 & 1.274 & 0.212 \\
\hline
\end{tabular}

Confidence levels are given in brackets. $* * *$, and $* * *$ denote significance at $90 \%, 95 \%$, and $99 \%$ levels respectively.

When examining the variables that most affect the sovereign credit rating assigned by CRAs, the results show that four out of the nine variables, interest rate, government debt to GDP, GDP per capita, and labeling the country as developed or not, had a statistically significant relation with S\&P rating. These results agree with the outcome of Cantor and Packer (1996) that GDP per capita does affect S\&P's credit rating but, at the same time, contradicts their 
finding that growth in GDP affects the rating. When examining the factors that affect Moody's sovereign credit rating, it can be seen that only two variables showed a statistically significant effect on the scores assigned, and they were government debt to GDP and GDP per capita. According to OLS regression output, GDP, interest rate, corruption index, government debt to GDP, and GDP per capita were the five factors that had a statistically significant effect on Fitch's credit score. While each credit rating agency had a different set of factors affect its credit rating score, all three CRAs had two common characteristics: government debt to GDP and GDP per capita.

Table 5. Estimated ratings and deviation results

\begin{tabular}{|c|c|c|c|c|c|c|c|c|c|c|}
\hline \multirow[b]{2}{*}{ Country } & \multirow[b]{2}{*}{ Year } & \multicolumn{3}{|l|}{$S \& P$} & \multicolumn{3}{|l|}{ Moody's } & \multicolumn{3}{|l|}{ Fitch } \\
\hline & & $\begin{array}{l}\text { Actual } \\
\text { Rating }\end{array}$ & $\begin{array}{l}\text { Estimated } \\
\text { Rating }\end{array}$ & Deviation & $\begin{array}{l}\text { Actual } \\
\text { Rating }\end{array}$ & $\begin{array}{l}\text { Estimated } \\
\text { Rating }\end{array}$ & Deviation & $\begin{array}{l}\text { Actual } \\
\text { Rating }\end{array}$ & $\begin{array}{l}\text { Estimated } \\
\text { Rating }\end{array}$ & Deviation \\
\hline \multirow{7}{*}{ Kuwait } & 2018 & 21 & 18.58 & 2.42 & 21 & 18.18 & 2.82 & 21 & 17.95 & 3.05 \\
\hline & 2017 & 21 & 20.14 & 0.86 & 21 & 19.04 & 1.96 & 21 & 19.71 & 1.29 \\
\hline & 2016 & 21 & 20.77 & 0.23 & 21 & 19.97 & 1.03 & 21 & 20.23 & 0.77 \\
\hline & 2015 & 21 & 21.13 & -0.13 & 21 & 21.37 & -0.37 & 21 & 19.94 & 1.06 \\
\hline & 2014 & 21 & 21.72 & -0.72 & 21 & 21.76 & -0.76 & 21 & 21.00 & 0.00 \\
\hline & 2013 & 21 & 22.28 & -1.28 & 21 & 22.30 & -1.30 & 21 & 21.43 & -0.43 \\
\hline & 2012 & 21 & 22.42 & -1.42 & 21 & 22.29 & -1.29 & 21 & 21.36 & -0.36 \\
\hline \multirow{7}{*}{ Qatar } & 2018 & 20 & 18.76 & 1.24 & 20 & 20.19 & -0.19 & 20 & 19.93 & 0.07 \\
\hline & 2017 & 20 & 18.83 & 1.17 & 20 & 19.33 & 0.67 & 20 & 20.16 & -0.16 \\
\hline & 2016 & 20 & 18.40 & 1.60 & 20 & 18.65 & 1.35 & 20 & 20.51 & -0.51 \\
\hline & 2015 & 20 & 20.82 & -0.82 & 20 & 22.11 & -2.11 & 20 & 21.53 & -1.53 \\
\hline & 2014 & 20 & 21.25 & -1.25 & 20 & 21.84 & -1.84 & 20 & 22.00 & -2.00 \\
\hline & 2013 & 20 & 21.24 & -1.24 & 20 & 21.82 & -1.82 & 20 & 21.99 & -1.99 \\
\hline & 2012 & 20 & 21.40 & -1.40 & 20 & 21.95 & -1.95 & 20 & 21.66 & -1.66 \\
\hline \multirow{7}{*}{ Bahrain } & 2018 & 11 & 11.05 & -0.05 & 11 & 10.19 & 0.81 & 11 & 13.10 & -2.10 \\
\hline & 2017 & 10 & 11.01 & $\begin{array}{l}-1.01 \\
\end{array}$ & 10 & 11.17 & -1.17 & 10 & 13.09 & $\begin{array}{l}-3.09 \\
\end{array}$ \\
\hline & 2016 & 11 & 11.27 & -0.27 & 11 & 11.66 & -0.66 & 11 & 12.90 & -1.90 \\
\hline & 2015 & 14 & 12.53 & 1.47 & 14 & 13.46 & 0.54 & 14 & 13.10 & 0.90 \\
\hline & 2014 & 15 & 14.24 & 0.76 & 15 & 15.28 & -0.28 & 15 & 14.12 & 0.88 \\
\hline & 2013 & 15 & 14.28 & 0.72 & 15 & 15.16 & -0.16 & 15 & 14.01 & 0.99 \\
\hline & 2012 & 15 & 14.80 & 0.20 & 15 & 15.87 & -0.87 & 15 & 13.93 & 1.07 \\
\hline \multirow{7}{*}{ Oman } & 2018 & 12 & 13.65 & -1.65 & 12 & 14.82 & -2.82 & 12 & 13.58 & -1.58 \\
\hline & 2017 & 12 & 12.96 & -0.96 & 12 & 14.67 & -2.67 & 12 & 12.82 & -0.82 \\
\hline & 2016 & 14 & 14.22 & -0.22 & 14 & 15.95 & -1.95 & 14 & 13.84 & 0.16 \\
\hline & 2015 & 16 & 16.25 & -0.25 & 16 & 18.30 & -2.30 & 16 & 15.22 & 0.78 \\
\hline & 2014 & 18 & 17.66 & 0.34 & 18 & 19.41 & -1.41 & 18 & 15.62 & 2.38 \\
\hline & 2013 & 18 & 17.69 & 0.31 & 18 & 19.77 & -1.77 & 18 & 15.30 & 2.70 \\
\hline & 2012 & 18 & 17.44 & 0.56 & 18 & 19.39 & -1.39 & 18 & 15.11 & 2.89 \\
\hline \multirow{2}{*}{ UAE } & 2018 & 21 & 19.75 & 1.25 & 21 & 20.36 & 0.64 & 21 & 20.17 & 0.83 \\
\hline & 2017 & 21 & 20.35 & 0.65 & 21 & 20.56 & 0.44 & 21 & 20.69 & 0.31 \\
\hline
\end{tabular}




\begin{tabular}{|c|c|c|c|c|c|c|c|c|c|c|}
\hline & 2016 & 21 & 20.69 & 0.31 & 21 & 20.75 & 0.25 & 21 & 21.27 & -0.27 \\
\hline & 2015 & 21 & 20.34 & 0.66 & 21 & 20.35 & 0.65 & 21 & 21.17 & -0.17 \\
\hline & 2014 & 21 & 21.75 & -0.75 & 21 & 21.36 & -0.36 & 21 & 21.24 & -0.24 \\
\hline & 2013 & 21 & 22.05 & -1.05 & 21 & 21.62 & -0.62 & 21 & 21.06 & -0.06 \\
\hline & 2012 & 21 & 21.88 & -0.88 & 21 & 21.31 & -0.31 & 21 & 20.77 & 0.23 \\
\hline \multirow{7}{*}{$\begin{array}{l}\text { Saudi } \\
\text { Arabia }\end{array}$} & 2018 & 17 & 16.57 & 0.43 & 17 & 18.05 & -1.05 & 17 & 18.67 & -1.67 \\
\hline & 2017 & 17 & 17.00 & 0.00 & 17 & 19.13 & -2.13 & 17 & 18.17 & -1.17 \\
\hline & 2016 & 17 & 17.87 & -0.87 & 17 & 18.91 & -1.91 & 17 & 19.92 & -2.92 \\
\hline & 2015 & 19 & 18.83 & 0.17 & 19 & 20.33 & -1.33 & 19 & 20.26 & -1.26 \\
\hline & 2014 & 20 & 19.58 & 0.42 & 20 & 20.62 & -0.62 & 20 & 20.65 & -0.65 \\
\hline & 2013 & 20 & 19.26 & 0.74 & 20 & 20.09 & -0.09 & 20 & 20.74 & -0.74 \\
\hline & 2012 & 20 & 19.62 & 0.38 & 20 & 20.08 & -0.08 & 20 & 21.03 & -1.03 \\
\hline
\end{tabular}

A minus sign in deviation columns indicates underrating while a positive number indicates overrating

As seen in Table 5, Kuwait was the most overrated country among all GCC countries in 2018. Fitch overrated Kuwait by 3.05 notches, while Moody's overrated it by 2.82 notches for the same year. By taking the average of the three CRA scores, Kuwait was overrated by 2.76 notches, while on the other hand, Oman was underrated by 2.02 notches. Table 6 shows the countries that were the most overrated and underrated countries during the study period. The table shows that Kuwait was the highest overrated country in the region 7 times out of the 18 observations, where most of these overratings came from Fitch. On the other hand, Qatar was the most underrated country in the region, 9 times out of 21.

Table 6. Most overrated and underrated countries

\begin{tabular}{|c|c|c|c|c|c|c|}
\hline & S\&P & & Moody's & & Fitch & \\
\hline Year & $\begin{array}{l}\text { Most } \\
\text { Overrated }\end{array}$ & $\begin{array}{l}\text { Most } \\
\text { Underrated }\end{array}$ & $\begin{array}{l}\text { Most } \\
\text { Overrated }\end{array}$ & $\begin{array}{l}\text { Most } \\
\text { Underrated }\end{array}$ & $\begin{array}{l}\text { Most } \\
\text { Overrated }\end{array}$ & $\begin{array}{l}\text { Most } \\
\text { Underrated }\end{array}$ \\
\hline 2018 & Kuwait & Oman & Kuwait & Oman & Kuwait & Saudi \\
\hline 2017 & Qatar & Bahrain & Kuwait & Oman & Kuwait & Bahrain \\
\hline 2016 & Qatar & Saudi & Qatar & Oman & Kuwait & Saudi \\
\hline 2015 & Bahrain & Qatar & UAE & Oman & Kuwait & Qatar \\
\hline 2014 & Bahrain & Qatar & $\mathrm{n} / \mathrm{a}$ & Qatar & Oman & Qatar \\
\hline 2013 & Saudi & Kuwait & $\mathrm{n} / \mathrm{a}$ & Qatar & Oman & Qatar \\
\hline 2012 & Oman & Kuwait & $\mathrm{n} / \mathrm{a}$ & Qatar & Oman & Qatar \\
\hline
\end{tabular}

n/a: indicates that all countries were underrated by Moody's

In examining the model's accuracy, it can be seen from Table 7 that the model produced the same rating as the S\&P 15 times, which is $35.7 \%$, exceeding that of Moody's and Fitch. The model was least consistent in estimating Fitch's ratings where there was a difference of more than three notches $11.9 \%$ of times. That deviation can be explained by the adjusted $R$ square of the Fitch model that was the lowest compared to the others. 
Table 7. Model Accuracy Analysis

\begin{tabular}{lllllll}
\hline & S\&P & & Moody's & Fitch \\
\hline $\mathbf{1}>$ diff & 15 & $35.7 \%$ & 10 & $23.8 \%$ & 12 & $28.6 \%$ \\
\hline $\mathbf{2}>$ diff $>\mathbf{1}$ & 24 & $57.1 \%$ & 19 & $45.2 \%$ & 16 & $38.1 \%$ \\
\hline $\mathbf{3}>$ diff $>\mathbf{2}$ & 3 & $7.2 \%$ & 10 & $23.8 \%$ & 9 & $21.4 \%$ \\
\hline $\mathbf{d i f f}>\mathbf{3}$ & 0 & $0 \%$ & 3 & $7.2 \%$ & 5 & $11.9 \%$ \\
\hline & 42 & $100 \%$ & 42 & $100 \%$ & 42 & $100 \%$ \\
\hline
\end{tabular}

In this research, both mean error and mean absolute error (MAE) are used to examine the model's robustness. The mean error would indicate the deviation direction but not the magnitude since the pluses and minuses would offset each other. Therefore, it would not give the true magnitude of the error. Table 8 shows that S\&P ratings are more likely to underrate Oman while they are likely to overrate Saudi Arabia. Mean absolute error (MAE) is used to measure the magnitude of the deviation between the actual rating and the forecasted rating produced by the model. The higher the MAE, the further the model is from the actual rating. From Table 8, it can be seen that S\&P had the lowest mean absolute deviation of 0.789 notches while the other two CRAs had the same absolute error of 1.160 notches.

Table 8. Model Error Analysis

\begin{tabular}{lllllll}
\hline & S\&P & & Moody's & & Fitch \\
& Mean Error & MAE & Mean Error & MAE & Mean Error & MAE \\
\hline Kuwait & -0.007 & 1.01 & 0.299 & 1.36 & 0.770 & 0.99 \\
\hline Qatar & -0.099 & 1.25 & -0.840 & 1.42 & -1.110 & 1.13 \\
\hline Bahrain & 0.260 & 0.64 & -0.257 & 0.64 & -0.465 & 1.56 \\
\hline Oman & -0.265 & 1.08 & -2.042 & 0.85 & 0.931 & 0.37 \\
\hline UAE & 0.028 & 0.79 & 0.097 & 0.47 & 0.091 & 0.30 \\
\hline Saudi Arabia & 0.182 & 0.43 & -1.031 & 1.03 & -1.350 & 1.35 \\
\hline GCC countries & $\mathbf{0 . 0 1 6}$ & $\mathbf{0 . 7 8 9}$ & $\mathbf{- 0 . 6 2 9}$ & $\mathbf{1 . 1 6 0}$ & $\mathbf{- 0 . 1 8 9}$ & $\mathbf{1 . 1 6 0}$ \\
\hline
\end{tabular}

\section{Conclusion}

Sovereign credit rating measures the country's ability and willingness to repay its debt. Having a high sovereign credit rating would result in more demand for the country's sovereign bonds and lower interest paid on them. This study aimed to examine the factors that mostly affect GCC countries' sovereign credit rating set by the three main credit rating agencies. Results have shown that every credit rating agency has its own set of variables that determines its score, and these variables differ from one credit rating agency to another. Out of the nine variables that were tested, four variables affected the S\&P rating. For Moody's, only two variables had a statistically significant effect on their rating. Finally, for Fitch, five variables affected their credit rating. The results also showed that Kuwait was the most overrated country in the region, and Oman was the most underrated country in the year 2018. The model proposed in this research showed that it can estimate the sovereign credit rating for GCC countries with an error margin of around one notch.

\section{References}

Afonso, A. (2003). Understanding the determinants of sovereign debt ratings: Evidence for the two leading agencies. Journal of Economics and Finance, 27(1), 56-74. Retrieved from https://www.repository.utl.pt/bitstream/10400.5/2736/1/wp22002.pdf

Afonso, A., Gomes, P. M., \& Rother, P. (2007). What 'hides' behind sovereign debt ratings?. ECB Working Paper No. 711. Retrieved from https://ssrn.com/abstract $=954705$

AlAli, M. S. (2015). The profitability of carry trade: A GCC perspective. Doctoral Thesis, School of Economics, 
Finance, and Marketing College of Business, RMIT University. Retrieved from https://researchbank.rmit.edu.au/eserv/rmit:161544/AlAli.pdf

AlAli, M. S. (2016). The use of Gulf Cooperation Council currencies in carry trade: A case study of United Arab Emirates Dirham. International Journal of Financial Research, 7(4), 117-128. https://doi.org/10.5430/ijfr.v7n4p117

AlAli, M. S., AlKulaib, Y. A., \& Bash, A. Y. (2017). Would basket pegged currencies work in carry trade? The case of Kuwaiti Dinar. International Research Journal of Finance and Economics, 160, 113-124. Retrieved from http://www.internationalresearchjournaloffinanceandeconomics.com/ISSUES/IRJFE_160-09.pdf

Bheenick, E. (2005). An analysis of the determinants of sovereign ratings. Global Finance Journal, 15(3), 251-280. https://doi.org/10.1016/j.gfj.2004.03.004

Cantor, R., \& Packer, F. (1996). Determinants and impact of sovereign credit ratings. Economic Policy Review, 2(2), 37-53. https://doi.org/10.2139/ssrn.1028774

Clark, E. (1997). Valuing political risk. Journal of International Money and Finance, 16, 477-490. https://doi.org/10.1016/S0261-5606(97)00008-9

Clark, E., \& Zenaidi, A. (1999). Sovereign debt discounts and the unwillingness to pay. Finance, 20, 185-199. https://doi.org/10.1142/9789813224940_0012

Destraz, S., \& Lahaye, R. (2012). Are credit ratings trustworthy? Empirical study on the dependence of corporate defaults to market risk within investment grade and speculative grade range. https://doi.org/10.2139/ssrn.2056849

Duran, M., \& Kucuksarac, D. (2017). Linkages between credit spreads and credit ratings. CBT Research Notes in Economics 1701, Research and Monetary Policy Department, Central Bank of the Republic of Turkey.

Ejigu, S. N. (2016). Determining internal factors affecting financial performance of insurance companies in Ethiopia. Research Journal of Commerce \& Behavioral Science, 5(6), 9-21.

Fahmi, E., Faisal, F., Habshi A., Hassan, W., Ariffin, F., Kuan, K. L., \& Azizakhon, Y. (2008). Revisiting OIC Fiqh Academy rules on organized tawarruq. Paper IBI006 of Part 1 of Certified Islamic Finance Professional (CIFP).

Frisch, D. (1995). Effects of corruption on development. Summary Report on Corruption. Democracy and Human Rights in Southern Africa, the Africa Leadership Forum and the Transparency International in Pretoria, South Africa.

Hamdi, A., Dewi, N., \& Herwany, A. (2014). The comparison analysis of determinant sovereign credit rating and its impact to stock market. Evidence for the Emerging Market Countries (July 5, 2014). https://doi.org/10.2139/ssrn.2420718

Haque, N., Mark, N. C., \& Mathieson, D. J. (1998). The relative importance of political and economic variables in creditworthiness ratings. IMF Working Paper No. 98/46. Retrieved from https://ssrn.com/abstract=882300

Hill, P., \& Faff, R. (2010). The market impact of relative agency activity in the sovereign ratings market. Journal of Business Finance \& Accounting, 37(9-10), 1309-1347. https://doi.org/10.1111/j.1468-5957.2010.02220.x

IMF Report. (2016). Diversifying government revenue in the GCC: Next steps, annual meeting of ministers of finance and central bank governors. October 26, 2016, Riyadh, Saudi Arabia. Retrieved from https://www.imf.org/external/np/pp/eng/2016/102616.pdf

Klein, A. (1998). Firm performance and board committee structure. The Journal of Law and Economics, 41(1), 275-304. https://doi.org/10.1086/467391

Kramaric, T., Miletic, M., \& Pavic, I. (2017). Profitability determinants of insurance markets in selected Central and Eastern European countries. International Journal of Economic Sciences, 6(2), 100-123. https://doi.org/10.20472/ES.2017.6.2.006

Lee, S. (1993). Relative importance of political instability and economic variables on perceived country creditworthiness. Journal of International Business Studies, 24, 801-812. https://doi.org/10.1057/palgrave.jibs. 8490256

Mankiw, G. (2007). Macroeconomics (6th ed.). Bahasa Indonesia, Worth Publisher. 
Mauro, P. (1995). Corruption and growth. The Quarterly Journal of Economics, 110(3), 681-712. https://doi.org/10.2307/2946696

Mellios, C., \& Paget-Blanc, C. (2006). Which factors determine sovereign credit ratings?. The European Journal of Finance, 12(4), 361-377. https://doi.org/10.1080/13518470500377406

Minescu-Ana, M. (2010). The determinants of sovereign credit rating: A worldwide study. The Business Review, Cambridge, 44(2), Summer.

Moosa, I. A., \& Al-Loughani, N. E. (2000). An exchange rate forecasting model when the underlying currency is pegged to a basket. Economia Internazionale/International Economics, 53(4), 537-550.

$\begin{array}{lllll}\text { OPEC } 2018 \text { Annual } & \text { Statistical } & \text { Bulletin. } & \text { (2020). Retrieved }\end{array}$ http://www.opec.org/opec_web/en/publications/202.htm

Pirdal, B. (2017). A comparative analysis of sovereign credit rating methods and credit default swaps. Bolu Abant İzzet Baysal Üniversitesi Sosyal Bilimler Enstitüsü Dergisi, 17(4), 107-124. Retrieved from https://dergipark.org.tr/en/pub/basbed/issue/38799/459070

Samuelson, P., \& Nordhaus, W. (1985). Economics (12th ed.). New York: McGraw-Hill Book Company.

Zheng, L. (2012). Are sovereign credit ratings objective? A tale of two agencies. Journal of Applied Finance \& Banking, 2(5), 43-61. Retrieved from http://www.scienpress.com/Upload/JAFB/Vol\%202_5_3.pdf

\section{Copyrights}

Copyright for this article is retained by the author(s), with first publication rights granted to the journal.

This is an open-access article distributed under the terms and conditions of the Creative Commons Attribution license (http://creativecommons.org/licenses/by/4.0/). 